\title{
A Moderate Millenarianism: Apocalypticism in the Church of Jesus Christ of Latter-Day Saints
}

\author{
Joseph M. Spencer
}

Department of Ancient Scripture, Brigham Young University, Provo, UT 84602, USA; joseph_spencer@byu.edu

Received: 27 March 2019; Accepted: 15 May 2019; Published: 25 May 2019

\begin{abstract}
The Church of Jesus Christ of Latter-Day Saints, the largest and arguably best-known branch of the Restoration movement begun by Joseph Smith, sustains a complex but living relationship to nineteenth-century marginal millenarianism and apocalypticism. At the foundations of this relationship is a consistent interest in the biblical Book of Revelation exhibited in the earliest Latter-Day Saint scriptural texts. The Book of Mormon (1830) affirms that apocalyptic visionary experiences like John's in the New Testament have occurred throughout history and even contains a truncated account of such a vision. It also predicts the emergence in late modernity of a fuller and uncorrupted account of such an apocalyptic vision, with the aim of clarifying the biblical Book of Revelation. In addition, however, Smith received an apocalyptic vision of his own in 1832 and produced a vision report that suggests that he understood The Book of Mormon's anticipations of apocalyptic clarification to come as much through ecstatic experience as through the emergence of new apocalyptic texts. In 1842, Smith created a ritualized version of his own apocalyptic experience, a temple liturgy that remains authoritative into the present. This lies behind the moderate apocalypticism of twenty-first century Latter-Day Saint religious experience.
\end{abstract}

Keywords: apocalypticism; Book of Revelation; Mormonism; the Book of Mormon; visionary experience; ritual

An astonishingly large number of small religious groups trace their origins to the American apocalyptic prophet Joseph Smith (for a good survey, see Bringhurst and Hamer 2007). By far the largest such body - and in many ways the best known - is the Utah-based Church of Jesus Christ of Latter-Day Saints. This denomination, the one usually meant when people speak of "Mormons", represents a kind of moderate middle within the stream of religious identities growing out of Smith's original millenarian focus (on Smith's apocalypticism generally, see Underwood 1993). Tending away from (and in some cases outright abandoning) Smith's apocalypticism are groups associated with the Reorganization movement of the 1860s (see Shipps 1985). Tending toward a more radical (or even radicalized) apocalypticism are groups associated with Mormon Fundamentalism, following the schism around the beginning of the twentieth century. The Church of Jesus Christ of Latter-Day Saints, for its part, holds the middle road and represents within itself a wide range of attitudes toward apocalypticism-from those approaching mainline Protestant comfort in the largely secular world to those approaching Evangelical fervor about the imminent collapse of states and governments (see Feldman 2015). Despite this diversity, the vast majority of Latter-Day Saints are as centrist as the institution to which they belong.

What holds the moderate middle in its mediating position is, arguably, the Utah-based Church's continued commitment to both scriptures and rituals that are deeply rooted in Smith's apocalypticism, but tempered by an acute need and desire to be a real part of the modern world (see Spencer 2011). It can in fact be argued that this moderate position is built directly into the scriptures and rituals at the heart of the larger religious movement launched by Smith. In this paper, I therefore look at how the New Testament's Book of Revelation is treated in the scriptures (and, to a lesser extent, the rituals) 
established by Joseph Smith during the first decade and a half of the Restoration movement. It is this focus on scripture and ritual that differentiates my approach here from that of Underwood (1993, pp. 97-111), who has argued more descriptively and historically that the early Latter-Day Saint tradition represented a form of moderate millenarianism. (Still others have, of course, given attention to the more radical aspects of early Latter-Day Saint millenarianism. See, for example, (Bracht 1990; Bloom 1992, pp. 79-128).) My argument, however, is, in a nutshell, that The Book of Mormon establishes a strong sense of anticipation regarding the fulfillment of the Book of Revelation's apocalyptic predictions, but that a later revelation to Smith—combined with Smith's development of a temple liturgy—sublimates such anticipation by refocusing it on the mundane but sacred work of building a religious community. This is to say, in the end, that the history of the Latter-Day Saint movement in America confronts the same problem faced by European eschatological thinking, as explored by Jacob Taubes, but refuses to outsource the work of building community to the secular or political world (see Taubes 2009, pp. 118-22).

This special issue of the Journal of Religions takes twenty-first-century apocalypticism as its focus. It is for this reason that I wish to emphasize the continuity between the uses of apocalyptic Christian texts in Latter-Day Saint scripture produced already in the early 1830s and twenty-first-century Latter-Day Saint religious practices. However, I do not here provide anything like a bridging history of the reception of Latter-Day Saint scripture between the 1830s and the 2010s, within the mainstream Latter-Day Saint tradition or comparatively within other branches of the Restoration movement. Nor do I here address the complex history of Latter-Day Saint liturgical practices, establishing direct continuity between the 1840s and the present or differentiating the distinct liturgical practices among the various branches of Smith's religious tradition. Instead, I take the moderate millenarianism of the contemporary Latter-Day Saint tradition as an empirical given and attempt, here, to provide an exegetical argument regarding apocalyptic texts, as well as their incorporation into liturgy, that might provide one explanation for the roots of the moderate millenarianism of the contemporary Latter-Day Saint mainstream.

\section{The Apocalypse in Antebellum America}

Surveys of the reception history of the Book of Revelation-both popular (see, for example, (Kirsch 2006)) and academic (see, for example, (Chilton 2013)) — generally give some attention to the way that this biblical book was read in the early history of the United States of America. Academic attention, however, tends to favor the other side of the Atlantic in addressing early modern interest in the Apocalypse (see, for instance, (Firth 1979; Burdon 1997; Johnston 2011)) or tends to treat the question of American apocalypticism as in many ways derivative of the intense apocalyptic interest in England between the seventeenth and the nineteenth centuries (see, for instance, Gilsdorf 1989; Zakai 1992). Where attention is given to what might be called natively American approaches to Revelation before the civil war, focus usually and understandably comes to settle on the Millerite phenomenon, the beginnings of Adventism (see Kirsch 2006, pp. 183-87; Chilton 2013, pp. 110-12; for specialized studies, see Numbers and Butler 1987). One finds (as in, for example, (Kovacs and Rowland 2004)) only the occasional nod to the United Society of Believers in Christ's Second Appearing (popularly called the Shakers) or to the Church of Jesus Christ of Latter-Day Saints (popularly called the Mormons), let alone to other natively American religious movements before the end of the nineteenth century. (The major exception in the literature is (Harrison 1979), as well as an in-press study of apocalypticism in the early Latter-Day Saint tradition specifically: (Blythe forthcoming).)

The followers of William Miller-like those of Ann Lee or Joseph Smith-inherited in crucial ways the transplanted millenarianism of the Puritans (especially the idea of the "sacred errand"' see (Miller 1956)). They also, however, developed unquestionably distinct apocalyptic traditions, not only regarded by those within the mainstream as being outside the mainstream, but also deliberately and in some ways advantageously positioning themselves outside the mainstream (see (Moore 1986)). Perhaps what especially distinguished the apocalypticism of these more marginal and marginalized 
traditions from that of the mainstream was the very fact of their apocalypticism. As one historian puts it, "in mainstream American Protestantism from the late eighteenth to the early twentieth century", apocalypticism was a "dog whose barking, muted from the outset, became ever fainter until it was little more than a whimper" (Moorhead 2000, p. 72). A genuinely popular revival of American Christian apocalypticism closer to the mainstream would not occur until the twentieth-century rise of fundamentalism. At that point, as reception histories routinely point out, Cyrus Scofield's Reference Bible popularized John Nelson Darby's late-nineteenth-century premillennialist reading of biblical prophecy (see Kirsch 2006, pp. 190-201; Chilton 2013, pp. 112-19).

Of course, it would be a mistake to suggest that Millerites, Shakers, and Latter-Day Saints represented a novum, entirely or even largely unprecedented in the early Republic. Apocalyptic interpretations of the American revolution emerged at the margins of the mainstream, and other sects less often commented on (such as the sect originating with Jemima Wilkinson), appeared in the wilderness of American Christianity in the last decades of the eighteenth century and the first decades of the nineteenth century. Nat Turner's apocalypticism, which spurred a slave rebellion, dates to this same period, as does the Stone-Campbell movement, which not only worked out its own apocalyptic interpretations of scripture but also provided the Church of Jesus Christ of Latter-Day Saints with many of its earliest converts, thanks to the conversion of Alexander Campbell's disciple Sidney Rigdon (for an outline of all these visible but non-mainstream apocalyptic movements, see (Stein 2000, pp. 110-17)).

Although the Latter-Day Saints thus find a place among numerous marginal apocalyptic sects and movements in antebellum American Christianity, there are unique aspects of their approach visible from the beginning, which become especially clear as their native moderate apocalypticism continues into the twenty-first century. Not only did Joseph Smith embrace the apocalyptic and offer specific interpretations of biblical apocalyptic texts, he presented his apocalypticism and interpretations to the world through the introduction of new scripture, creating an expanded canon of Christian sacred writings (for recent reflections on this expansion of the canon, see (Van Dyke et al. 2018; Ashurst-McGee et al. forthcoming)). Smith's religious movement was hardly the only one to introduce new sacred writings in the antebellum context, to be sure (see Maffly-Kipp 2010), but it arguably made the most radical such gesture (see Holland 2011). Further, unlike most (or all) other antebellum examples of uniquely American scripture, Smith's texts became the foundation for a stable and consistently growing new religious tradition. As Hardy (2018, p. 73) notes, "even though new scripture is produced regularly, very little of it has a continuing authoritative role within a long-term religious community". He estimates that "within the last thousand years, there are only about a dozen books or collections of writings that could be judged to have attained world scripture status". The Book of Mormon, along with Smith's revelations in Doctrine and Covenants and The Pearl of Great Price, finds itself within a vanishingly small class of successful new scripture. And it is within Smith's expanded canon that one finds his tradition's most enduring apocalyptic gestures, as well as its most staid interpretations of biblical apocalyptic texts.

The Book of Mormon and the various revelations received by Smith can be scoured for apocalyptic themes and texts. The Book of Mormon's obvious investment in the Book of Isaiah, apocalyptically interpreted, serves in many ways as a cornerstone-and it continues to spur a somewhat less moderate version of Latter-Day Saint apocalypticism into the twenty-first century (see, for instance, (Gileadi 2005; Gileadi 2013)). More general millenarian themes and images can be found throughout The Book of Mormon and Smith's revelations, themes and images that drew the attention of the earliest readers of these texts more consistently than recent readers (see Underwood 1993, pp. 76-96; Givens 2002, pp. 62-88, 240-46). For the purposes of the present study, however, I consider quite specifically the way that Smith's scriptural corpus directly engages with the biblical Book of Revelation. References both implicit and explicit to the biblical Apocalypse are not only frequent but thematically crucial to uniquely Latter-Day Saint scripture. And, according to my argument, it is in the complex entanglement of various treatments of the Book of Revelation within Smith's scriptures that this tradition's unique moderate millenarianism finds its foundation. 


\section{The Book of Revelation in The Book of Mormon}

The Book of Mormon often borrows from New Testament texts, including Revelation, simply by way of composing its basic Christian idiom. As Hardy (2010, pp. 5-6) points out, "Even a cursory glance reveals that the Book of Mormon wants to be seen as a companion to the Bible. It is divided into books named after prophets; biblical phrases and even chapter-length quotations are scattered throughout; and it is written in the diction of the Authorized Version, including the general use of archaic words such as thou, doth, hath, and all manner of verbs ending in-eth". Frederick (2016, p. 131) has argued that the constant use of biblical language in Latter-Day Saint scripture serves at least two functions. First, "Mormon scripture employs the rhetoric of allusivity as a means of juxtaposition with the Bible in order to procure literary authority with a nineteenth-century audience". Second, the presence of biblical language allows for "a remarkable deconstruction and reconstruction of the Bible", "a lengthy and complex discourse" between biblical texts and uniquely Latter-Day Saint texts (see also Frederick 2018).

Many of The Book of Mormon's interactions with Revelation fit nicely into these two categories. A simple example of the former sort is the borrowing of Revelation 22:17 in Alma 42:27: "Therefore, $\mathrm{O}$ my son, whosoever will come may come and partake of the waters of life freely" (all quotations from The Book of Mormon come from (Skousen 2009)). Here, a biblical phrase, familiar to nineteenth-century readers from Revelation, appears in a conversation between a Book of Mormon father and his son. This allusion creates familiarity for the presumed first readers of the book. An example of the second sort of biblical borrowing is the eventual and apparently deliberate rejection of the Apocalpyse's notion of suffering in a "lake of fire and brimstone" (see Revelation 19:20; 20:10; 21:18). As Turley (forthcoming) shows, although this image appears in the first half of The Book of Mormon, the volume then presents a story of martyrdom (see Alma 14) that spurs, within The Book of Mormon itself, a critique of the image. Significantly, this image of damnation then disappears from the text from that point to the volume's end. This example finds The Book of Mormon attempting a deconstruction and reconstruction of a recurring apocalyptic image from the Book of Revelation, theologically and narratively inventive in nature.

Apart from such subtle intertextual borrowings, however, The Book of Mormon has overt and unmistakable interactions with Revelation, and these draw my attention here. The sorts of Book of Mormon passages in question reflect on the significance of Revelation as a whole, more systematically than the examples cited previously. Twice in the volume, one finds explicit comments on the total significance of the New Testament's Apocalypse. Each of these deserves individual comment in turn (for a general introduction to the contents of The Book of Mormon, see (Givens 2009)).

First, early in the book, one finds an apocalyptic vision experienced by a certain Nephi, a founding figure for the New-World Israelite colony whose story the volume recounts. This vision is not only replete with allusions to Revelation, the text explicitly equates Nephi's vision with John's (for some discussion, see Hopkin 2016). The vision account ends with Nephi seeing “a man ... dressed in a white robe", identified as "one of the twelve apostles of the Lamb" (1 Nephi 14:19-20). Nephi says that "the name of the apostle of the Lamb was John, according to the word of the angel" (14:27). As Nephi sees John in a vision, an angelic guide explains that the apostle will contribute an account of "the end of the world" to a "book" that would proceed "out of the mouth of the Jew" (14:22-23)—a phrase used earlier in the vision account to describe the Christian Bible (see 13:23). The angel then connects Nephi's visionary experience to John's in Revelation. He tells Nephi, "the things which this apostle of the Lamb shall write are many things which thou hast seen" (14:24). Further, the angel promises that Nephi will see "the remainder" of John's apocalyptic vision, "but the things which thou shalt see hereafter thou shalt not write, for the Lord God hath ordained the apostle of the Lamb of God that he should write them" (14:24-25).

Although the text of The Book of Mormon here never uses the phrase "Book of Revelation", it is clear that it means to connect Nephi's vision to the last book of the New Testament. This might well lead readers to set Nephi's vision side by side with Revelation, despite the fact that Nephi is allowed only 
to record part of the visionary experience he shares with John. But the text also warns such readers; although "the things which [the apostle of the Lamb] shall write are just and true", the angel says, they are in some ways compromised (14:23). He tells Nephi that "at the time they proceeded out of the mouth of the Jew, ... the things which were written were plain and pure and most precious and easy to the understanding of all men" (14:23), but because of events early in Christian history, the plain and the precious in the Christian Bible is no longer readily interpretable. The angel explains earlier that "when [the Bible] proceeded forth from the mouth of a Jew, it contained the fullness of the gospel of the Lamb", but then a "great and abominable church" will have "taken away from the gospel of the Lamb" - and "from the book" itself- "many parts which are plain and most precious; and also many covenants of the Lord have they taken away" $(13: 24,26,28)$. (On the meaning of this corruption of text and its relationship to the "great and abominable church", see especially (Robinson 1998; Spencer 2016a, pp. 2-11).)

The Book of Revelation, this text from early in The Book of Mormon avers, is problematic in the canonical form in which it currently circulates. It still represents the vision of John, but it has been in certain ways compromised or corrupted, leading Christianity to "stumble, yea, insomuch that Satan hath great power" (1 Nephi 13:29). Unfortunately, Nephi's own record of the same visionary experience is truncated. The angel tells him not to write much of what he sees, since "the Lord God hath ordained the apostle of the Lamb of God that he should write them" (14:25). Thus, although presumably believers might find some parts of Revelation clarified through Nephi's vision account, much of the Apocalypse remains inaccessible "to the understanding of all men" (14:23). Nephi's angelic guide, however, at least briefly refers to a possible solution to this problem. He explains, "And also others which have been, to them hath [God also] shown all things, and they have written them. And they are sealed up to come forth in their purity, according to the truth which is in the Lamb, in the own due time of the Lord, unto the house of Israel" (14:26). According to the angel, although John's vision account is corrupted and Nephi's vision account is truncated, there are other written accounts of the same apocalyptic visionary experience, and these are sealed so as to retain their "purity" until the moment is right for their release to the public.

The situation regarding apocalyptic visions, according to Nephi's vision in The Book of Mormon, is rather dire. John's apocalyptic vision familiar from the New Testament has been given many times in history to different individuals. In the case of John's widely available account of the vision, however, one can read only a corrupt or problematic text. The Book of Mormon of course contains its own account of the same vision, but this comes into general circulation only centuries and centuries after John's account, and the account there is dramatically abbreviated. Finally, although there are other, purer and more complete accounts of the same visionary experience in existence, they are as yet not in circulation. The true apocalyptic vision is, according to Nephi's angel, triply unavailable to the world: obscure or truncated or unavailable.

Nephi later comments further on the visions that are sealed up and unavailable. These comments occur in the context of a prediction regarding the emergence of The Book of Mormon, which Nephi has witnessed in his own apocalyptic vision of history. In describing the gold plates from which The Book of Mormon would be translated (he calls these plates simply "the book"; for some discussion, see (Cloward 1998; Hardy and Hardy 2016; Spencer 2016b)), he claims that "the book shall be sealed. And in the book shall be a revelation from God from the beginning of the world to the ending thereof" (2 Nephi 27:7). This comment identifies the alleged location of a supposedly uncorrupted version of the apocalyptic vision behind Revelation: in the gold plates Joseph Smith claimed to unearth in upstate New York in 1827 (for background, see (Bushman 2005, pp. 41-61)). Nephi, however, goes on: "Wherefore because of the things which are sealed up, the things which are sealed shall not be delivered in the day of the wickedness and abominations of the people.... And the revelation which was sealed shall be kept in the book until the own due time of the Lord" (2 Nephi 27:8, 10). From the gold plates, apparently, Smith would only translate "the words which are not sealed" (27:15). Thus, although Nephi identifies an actual textual locus for an uncorrupted version of the oft-granted 
apocalyptic vision, he explains that that locus remains "hid from the eyes of the world" by divine design (27:12). Only when God "shall see fit ... to reveal all things unto the children of men" (27:22) will the gold-plates account of the full apocalyptic vision be made available (descriptions of Smith's gold plates have been collected in Morris 2019, pp. 370-455).

The second key moment in the larger Book of Mormon clarifies the nature of this "sealed" portion of Smith's gold plates. Late in the volume, one finds a brief sketch of a non-Israelite people's New-World history, in ways parallel to the history of the Israelite colony that occupies most of the book. This non-Israelite people has a founding prophet figure much like Nephi-known only by the name "the brother of Jared" - and this figure similarly inaugurates his people's history with an apocalyptic vision. After an encounter with the premortal Jesus Christ, the brother of Jared sees a vision of "all the inhabitants of the earth which had been and also all that would be" (Ether 3:25). Then, however, as the vision concludes, he hears this from God: "Write these things and seal them up, and I will shew them in mine own due time unto the children of men" (3:28). Further, God tells him, "And behold, when ye shall come unto me, ye shall write them and shall seal them up, that no one can interpret them; for ye shall write them in a language that they cannot be read.... For behold, the language which ye shall write I have confounded" $(3: 22,24)$. Only with the aid of "two stones", specially prepared to "magnify" the sealed writings "to the eyes of men", can they be read (3:23-24).

Here, then, another Book of Mormon figure experiences an apocalyptic vision, and this one is instructed to write the experience up in its purity, and then to seal it. The narrator of the story then interrupts to explain that he has written onto the gold plates of The Book of Mormon "the very things which the brother of Jared saw" (Ether 4:4), although he has also been "commanded" to "seal them up", along with "the interpretation thereof" (4:5). This text thus retroactively clarifies the meaning of Nephi's comments earlier in the volume. The full but sealed apocalyptic vision in the gold plates that Nephi claims will come forth only at the right time is just that of the brother of Jared, copied into the gold plates by a later editor and then sealed up.

This already suggests a connection with Revelation. But then this connection is made clearer in as the story of the brother of Jared continues. The interrupting editor quotes God as saying that the sealed vision "shall not go forth unto the Gentiles until the day that they shall repent of their iniquity and become clean before the Lord. And in that day that they shall exercise faith in me, even as the brother of Jared did, that they may become sanctified in me, then will I manifest unto them the things which the brother of Jared saw, even to the unfolding unto them all my revelations" (4:6-7; see Hardy 2010, pp. 241-46; Spencer 2014, pp. 68-72). A paragraph or two later in the text, the narrator addresses the reader: "Behold, when ye shall rend that veil of unbelief which doth cause you to remain in your awful state of wickedness and hardness of heart and blindness of mind, ... then shall my revelations which I have caused to be written by my servant John be unfolded in the eyes of all the people" (4:15-16). Here, the text links together, explicitly, the unveiling of the sealed portion of Smith's gold plates and the ultimate and universal latter-day clarification of Revelation. The effective equivalence of the visionary experiences of John and the brother of Jared is asserted in Nephi's record, but the editor's comments later in The Book of Mormon promise that the circulation of the one (gold-plates) vision account will fully clarify the other (biblical) vision account.

Here, then, The Book of Mormon's two key moments come together. One assesses Revelationclaiming that it has been corrupted or confused-and also insists that Joseph Smith's gold plates will contain a replacement text that God will eventually bring forth. The other describes the origins of the replacement text and confirms that its eventual release is meant to bring universal clarity to Revelation. When these two moments are brought together, moreover, they give the publication of The Book of Mormon in 1830 a distinct temporal effect. As a book translated by the gift and power of God, it is supposed to mark the reemergence of revelatory phenomena (see, on this point, Givens 2002, pp. 72-88). And yet, The Book of Mormon makes its intervention in a deliberately modest fashion. That is, it presents itself only as a foretaste of the real revelatory experience to come, which it identifies (Shipps 
1985, pp. 51-53). The true revelation, for which The Book of Mormon only serves as the forerunner, is the full exposition of John's Apocalypse from the New Testament.

The Book of Mormon, in other words, is principally projective, a modest revelation (albeit of five or six hundred pages!) that aims to spur a still more audacious revelation: the unsealing of sealed visions that will finally clarify the perpetually mysterious Apocalypse that closes the Christian Bible. It is unsurprising that a handful of enterprising (but quickly marginalized) Latter-Day Saints have, over the course of the church's history, issued alleged translations of the sealed vision of the brother of Jared (see especially Nemelka 2005). Believers in The Book of Mormon perhaps must look forward to the fuller revelation promised within the volume, and therefore must look forward to a universal exposition of Revelation. Certainly, in many ways, the apocalyptic spirit remains alive and well in the twenty-first century Church. Nonetheless, I wish to show here that Joseph Smith may have himself believed that the revelatory event projected by The Book of Mormon actually occurred already, at least in some sense, in 1832. And because Smith later wove his 1832 clarifications of the Apocalypse into a temple liturgy that remains at the heart of Latter-Day Saint worship today, this has major implications for the shape of twenty-first-century Latter-Day Saint apocalypticism.

\section{The Book of Revelation after The Book of Mormon}

On 16 February 1832, Joseph Smith was at work on his "New Translation" of the Christian Bible (sometimes called "the Joseph Smith translation"). At the time, this took the shape of a full dictation of the biblical text, with Smith's revisions of the King James Version worked directly into what he dictated to his scribes. For nearly a year, Smith had been dictating the New Testament's four gospels with revisions, coming to John 5 that day in February. As Smith and his scribe, Sidney Rigdon, recounted, they were that day "in the Spirit" as they "sat doing the work of translation" (D\&C 76:11, 15; all quotations of the relevant vision account, canonized in the Doctrine and Covenants, come from (Godfrey et al. 2013, pp. 179-92)). When they came to John 5:29, they reported, "the Lord touched the eyes of our understandings and they were opened and the glory of the lord shone round about" (D\&C 76:19). This inaugurated a series of visions, simultaneously experienced by both Smith and Rigdon, which they compiled in written form into a single vision account (for context and some analysis, see Woodford 2010). The experience—and especially its theologically transformative content—were significant enough for early Latter-Day Saints that the resulting document came to be known simply as "The Vision" despite the fact that Smith claimed to have many visions over the course of his career. This vision account would again draw in crucial ways on Revelation.

Crucial to understanding the importance of the 1832 vision is the likelihood that it marked one of the most substantial breaks in the development of Joseph Smith's prophetic self-understanding. Numerous details suggest that Smith saw the vision as inaugurating a new era in the early history of his church. These deserve summary, since they collectively indicate that Smith regarded his 1832 vision as an apocalyptic vision of particular importance-a vision along the lines of John's or Nephi's or the brother of Jared's.

First, Smith apparently regarded the New Translation project as in some sense completed after the vision. Upon reception of the vision, he abandoned complete dictation and transcription of the revised biblical text, pursuing instead a sketchier method of biblical annotation. Consequently, although he had taken nearly two years to revise the first half of Genesis and most of the four gospels, Smith revised the rest of the Bible in only a year's time (for the texts, along with some contextualizing scholarship, see (Faulring et al. 2004)). This complete transformation of the project suggests that Smith viewed it as having been in some way aimed at producing the vision. Second, efforts at gathering Smith revelations into manuscript books indicate that Smith and his scribes regarded the vision as qualitatively distinct from previous revelations. One of Smith's scribes had, by early 1832, already been compiling Smith's revelations into a single manuscript book, which still had much room for further additions in February 1832. Instead of adding the vision to the same single manuscript book, however, Smith's scribe began a second manuscript revelation book and inserted as its first entry the full vision account (see Jensen et 
al. 2009, pp. 407-33). This surprising move suggests that Smith and his associates regarded the new vision as the beginning of something new.

Third, subsequent efforts at printing Smith's revelations confirm this impression. The first attempt at printing a volume of Smith's revelations was aborted late in production due to mob violence in the summer of 1833 (see Romig and Siebert 1990). The reconstruction of the intended final shape of the volume suggests that it was meant to conclude its chronological presentation of Smith's revelations with the last-received revelation prior to the vision of 1832 (see Jensen et al. 2011, pp. 173-93). Since Smith had received more than twenty revelations between the vision and the aborted production of the volume, the apparent decision to conclude it with the revelation received last before the 1832 vision suggests that there may originally have been plans to create a second volume that would open with Smith and Rigdon's vision. Fourth, it seems the vision of February 1832 spurred Smith to undertake, for the first time, to write an autobiographical sketch, which he produced in an unfinished form in mid-1832 (and perhaps as early as March of 1832; see (Davidson et al. 2012, pp. 7-9)). It thus seems likely that Smith meant to produce, in the wake of his new visionary experience, a narrative account of his early visionary experiences that would lead up to and contextualize this most radical of his visions, fully apocalyptic in nature. This would seem to be confirmed by the fact that other revelations and visions received in the wake of the February 1832 vision collectively spell out the basics of what would become Smith's most radical theological contribution. Holifield (2003, p. 337) thus makes the "1832 vision received while [Smith] and Rigdon retranslated the gospel of John" the beginning of "a new cosmology". Bushman (2005, p. 195) has in turn labeled the series of revelations beginning with the vision "the exaltation revelations".

There is thus every reason to think that Smith's 1832 vision alongside Rigdon marked a deep shift in the early development of Latter-Day Saint theology, and in Smith's own self-understanding as a prophet. With this vision, he apparently regarded himself as having joined the ranks of the apocalyptic prophets. He was not only a divinely gifted translator of ancient texts and an occasional receiver of verbal communications from God, he was also an apocalyptic seer. It is therefore of deep importance that, as Frederick (2016, pp. 95-96) has especially shown, the "exaltation revelations" stage a dramatic revision of Smith's apparent relationship to the received Christian Bible. Where before February of 1832, Smith's scriptural and revelatory output echoed, alluded to, and expanded on its biblical sources, from that point forward Smith's revelations began to stage full-blooded inversions of the biblical text. Frederick's study of this phenomenon focuses more or less exclusively on the intertextual relationship between Smith's scriptures and revelations and the Gospel of John (especially John's prologue). But more central in my view, from the outset of Smith's exaltation revelations, is the interaction between Smith's revelations and the Apocalypse.

The particular relevance of Revelation is clear from the first words of Smith and Rigdon in the jointly authored vision report. "We Joseph \& Sidney being in the spirit on the sixteenth of February in the year of our Lord one thousand eight hundred and—thirty two ... ". (D\&C 76:11). These words follow a few paragraphs of preamble, part of which presents the voice of God issuing promises to readers. In a parallel gesture, Revelation opens with a promise-laden preamble, partially in the voice of God. Revelation's preamble then gives way to the following: "I John, ... was in the Spirit on the Lord's day" (Revelation 1:9-10). The Smith-and-Rigdon vision account replaces "the Lord's day" with "the year of our Lord", and it represents the experience of a pair of visionaries rather than the singular John, but their vision report nonetheless begins by subtly establishing its filial relationship with the Apocalypse. Confirming this filiation, the earliest extant copy of the 1832 vision describes the vision as concerning "the economy of God and his vast creation" (Godfrey et al. 2013, p. 183). This is the same technical terminology Smith used to describe the meaning of "the Book which John saw which was sealed" in Revelation 5:1, specifically within a document (titled "Revelation Explained") dating about a month after the vision. "We are to understand", Smith's scribe wrote at his dictation, that the sealed book from Revelation "contains the revealed will mysteries and works of God, the hidden things of his economy concerning this Earth during the seven thousand years of its continuance or its temporal 
existence" (D\&C 77:6; (Godfrey et al. 2013, pp. 210-11), original orthography retained). It seems clear that Smith and his scribes meant to present the 1832 vision as related to an unsealing of the sealed book mentioned in the Apocalypse.

Returning to the vision, one finds the relevance of Revelation further confirmed when the report describes the very first visionary experience. The description weaves together language from throughout the New Testament, but it settles ultimately on the scene from Revelation 4-5 (in which the image of the sealed book first appears): "the glory of the lord shone round about and we beheld the glory of the son on the right hand of the Father and received of his fulness and saw the holy Angels and they who are sanctified before his throne worshiping God and the lamb for ever and ever" (D\&C 76:19-21). One finds here in succession allusions to Luke 2:9 (the appearance of the angel to the shepherds in the Lukan nativity story), Acts 7:55 (the vision of the Father and the Son by Stephen at his martyrdom), John 1:16 (the reception of the divine fullness in John's prologue hymn), and the whole complex heavenly worship scene of Revelation $4-5$. The first three allusions are more exact intertextual borrowings, excerpting of exact phrases. The final allusion to Revelation instead reconstructs in inexact language a biblical scene described over the course of two chapters in the Apocalypse. Thus, this opening of the actual vision account by Smith and Rigdon draws various New Testament theophanic moments into John's specific experience of the heavenly throne room. The messianic announcement to Bethlehem's shepherds, the dying vision of the first Christian martyr, and the glorious Johannine witness of the Baptist-all these rise up to the level of the apocalyptic vision, as if the whole of the New Testament finds its spiritual telos in its last book.

As the vision continues, Smith and Rigdon report seeing "an angel of God who was in authority in the presence of God who rebelled against the only begotten son whom the father loved who was in the bosom of the father" (D\&C 76:25). This angel, they explain, "was thrust down from the presence of God and the son and was called perdition" (76:25-26). Commanded to "write the vision" (76:28), they explain that they "beheld satan that old serpent even the devel who who rebelled against God and saught to take the kingdom of our God and his christ wherefore he maketh war with the saints of God and encompasseth them round about" (76:28-29, original spelling and errors retained here and in subsequent quotations). Here, the visionary description of Satan derives from the Book of Revelation. Revelation 12:9 speaks of "that old serpent, called the Devil, and Satan", Revelation 12:10 speaks of "the kingdom of our God, and the power of his Christ", and Revelation 13:7 speaks of one given "to make war with the saints, and to overcome them". Lesser but worth mentioning, Revelation 20:9 speaks of God's enemies as having "compassed the camp of the saints about". Here, the devil of the 1832 vision is thoroughly the devil of the Apocalypse.

There follows in the vision account a description of the suffering of the devil's followers. Here again one finds a series of New Testament allusions, but again the series culminates in a string of borrowings from Revelation. Satan's followers, the text explains, are "those who who know my power and have been made partakers thereof and have suffered themselves through the power of the devel to be overcome unto the denying of the truth and the defying of my power" (D\&C 76:30-31). This introduces the figures, but then (one encounters borrowings from John 17:12 and 2 Thessalonians 2:3 ("they are they who are the sons of perdition"; D\&C 76:32), from Mark 14:21 ("of whom I say it had been better for them to have never been born"; D\&C 76:32), from Romans 9:22 ("for they are vessels of wrath doomed to suffer the wrath of God with the Devel and his angels throughout all eternity"; D\&C 76:33), from Matthew 12:32 ("concerning whom I have said there is no forgivness for them in this world nor in the world to come having denied the holy ghost after having received it"; D\&C 76:34-35), from Hebrews 6:6 ("and having denied the only begoten son of the fathe crucifying him unto themselves and putting him to an open shame"; D\&C 76:35). After this series of New Testament borrowings, however, the description of these "sons of perdition" comes to a conclusion with clear and climactic borrowings from Revelation: "these are they who shall go away into the lake of fire and brimstone with the devel and his andels and the only ones on whom the seccond death shall have any power" (D\&C 76:36-37). Here, in succession, one finds the apocalyptic themes of "the lake of fire and brimstone" (see Revelation 
19:20; 20:10, 14, 15; 21:8), "the devil and his angels" (see 12:9), and the second death (see 2:11; 20:6, $14 ; 21: 8)$. Just as the portrayal of the devil in the 1832 vision derives from the Apocalypse, so does its portrayal of the devil's followers, although the vision account makes the apocalyptic presentation the climax of and conclusion to the assemblage of a variety of New Testament texts.

What emerges by this point is a clear pattern, which continues at least through the next several sequences of the vision report. In their descriptions of the sequences of the vision, Smith and Rigdon repeatedly weave together various New Testament texts, but they always bring them to a culmination with language drawn specifically from Revelation. In each case, a network of non-apocalyptic sources and images takes shape and then prepares for clear allusions to the Apocalypse. In this way, it seems that the vision report means to outline a series of hermeneutical keys for reading Revelation. Better put, the vision report alerts readers that Smith and Rigdon were experienced an apocalyptic vision that allowed them to make sense of the whole New Testament. They saw things that the non-apocalyptic New Testament explains in exoteric terms, but that Revelation describes or refers to in more strictly esoteric terms. It is thus that the vision seems meant to serve as a key to the Apocalypse. Having experienced an apocalyptic vision themselves, it seems Smith and Rigdon believed they could explain the basic meaning of the key apocalyptic vision from the Christian tradition, that of the New Testament's Book of Revelation.

The 1832 vision account serves as a hermeneutical key to the Apocalypse, but it serves equally as an invitation to have a similar apocalyptic experience. As previously noted, the account begins with a preamble in the voice of God. "I the Lord am merciful", the preamble states, "and gracious unto them who fear me and delight to honor them who serve me in righteousness and in truth" (D\&C 76:5). At this point in the earliest extant manuscript copy of the vision account, the handwriting of one of Joseph Smith's scribes (Frederick G. Williams) ends, and the report of God's voice continues in the hand of Joseph Smith himself: "great shall be their reward and Eternal Shall be their glory and unto them will I reveal all misteries yea all the hiden misteries of my Kingdom from days of old and for ages to come will I make Known unto them the good pleasure of my will concerning all things to come" (76:6-7; Godfrey et al. 2013, pp. 184-85). With these words, Smith's God issues a promise to every reader of the vision. She too can experience a vision like John's, one that would make Revelation clear. All can experience an exoteric vision that makes the esoteric plain. Smith and Rigdon provide a model, so to speak, for the reception and proper use of apocalyptic visions. One seeks a vision, receives it, and then uses it to sift and sort out the meaning of the biblical Apocalypse.

With this universal invitation to experience the apocalyptic, Smith's preamble to the vision report directly echoes The Book of Mormon. Nephi, in a few words of preamble to his account of his own apocalyptic vision, stresses the sameness of God "yesterday and today and forever" and so states, "For he that diligently seeketh shall find, and the mysteries of God shall be unfolded to them by the power of the Holy Ghost as well in this time as in times of old and as well in times of old as in times to come" (10:18-19). That Nephi means by these words to indicate that anyone can ask and receive his apocalyptic vision is clear from the narrative that immediately follows the vision report. When he finds that his older brothers have not "inquired of the Lord" to have the vision themselves-because, they explain, "the Lord maketh no such thing known unto us"- - he responds, "How is it that ye will perish because of the hardness of your hearts? Do ye not remember the thing which the Lord hath said?-if ye will not harden your hearts and ask me in faith, believing that ye shall receive, with diligence in keeping my commandments, surely these things shall be made known unto you" (15:8-11). Like Joseph Smith, Nephi apparently comes away from his own apocalyptic visionary experience convinced that it is open to anyone.

This connection between Joseph Smith and Nephi suggests a still-deeper connection between The Book of Mormon, published in 1830, and the vision account written up two years later in 1832 . The Book of Mormon creates for the believing reader a profound sense of anticipation, directing her to a coming revelation meant to clarify the New Testament's Apocalypse, which The Book of Mormon associates with the sealed portion of the gold plates. But it simultaneously leaves open the possibility 
that readers will experience something outside of any specific text. "And in that day that they shall exercise faith in me", the text explains in the voice of God, "then will I manifest unto them the things which the things which the brother of Jared saw, even to the unfolding unto them all my revelations. ... Behold, when ye shall rend that veil of unbelief ..., then shall my revelations which I have caused to be written by my servant John be unfolded in the eyes of all the people" (Ether 4:7, 15-16). Although believing Latter-Day Saints anticipate the eventual appearance of a text associated with the sealed portion of Smith's gold plates, this text-along with Nephi's encouragement to seek out an apocalyptic vision like his own-might just as well lead them to anticipate a non-textual apocalyptic experience. The Smith-and-Rigdon apocalyptic experience of 1832, coupled with its universalizing preamble, suggests that Smith and his earliest followers quickly came to believe that one did not need to wait for a mysterious text; one could directly experience what John and Nephi and the brother of Jared had all experienced. Smith and Rigdon claimed to have had such a vision, and they invited others to do the same.

The apocalyptic vision of 1832 thus might be seen as transforming (or completing the transformation of) The Book of Mormon's anticipation of a text behind the apocalyptic text. In the place of anticipating a sealed textual source that might serve as the hermeneutical key for Revelation, it encouraged (as certain passages in The Book of Mormon itself) anticipation of an experience behind the text, of an available experiential source that might provide every faithful individual with her own hermeneutical key for Revelation. Rather than looking solely or even primarily for something to be translated and published, Latter-Day Saints might begin looking for something to be undergone by all the faithful. In this way, from the very beginning of the Latter-Day Saint tradition, the biblical Apocalypse arguably became a spur to seek a kind of experience, one that Smith would spend the remainder of his life trying to determine how to give to his followers as universally as possible.

\section{The Book of Revelation Today}

It was Joseph Smith's sustained efforts between 1832 and his death in 1844 to bring his followers into a kind of apocalyptic visionary communion with himself that would keep average Latter-Day Saints on the apocalyptic spectrum. But it was the way that he would eventually create a universal apocalyptic experience for his followers - in the form of a temple-based liturgical experience-that would provide for the mainstream moderation of Latter-Day Saint apocalypticism into the twenty-first century.

That Joseph Smith worked to bring his followers to share in his visionary experiences is something he himself occasionally pointed out. For instance, in 1839 he taught publicly that "God hath not revealed anything to Joseph but what he will make known unto the Twelve \& even the least saint may know all things as fast as he is able to hear them" (Ashurst-McGee et al. 2017, p. 524). In a documented direct experience, one of Smith's close associates reported that he took him and another man into the woods in April 1834 and announced "Now brethen [sic] ... we will see some visions" (Baugh 2005, p. 385). Asking them to lie down with their heads on his arms, the trio experienced a vision of Adam and Eve in their ultimately exalted state. Similar experiences, but involving a variety of believers, reportedly occurred in connection with the 1836 dedication of the first temple Smith built (see Harper 2005). Smith occasionally publicly deplored his followers' ability to receive what he had received, however. In an 1844 sermon before "several thousand people", he claimed both that "if we have or Can receive a portion of knowledge from God by immediate revelation by the same source we can receive all knowledge", and that "I have tried for a number of years to get the minds of the Saints prepared to receive the things of God, but we frequently see some of them after suffering all they have for the work of God will fly to peaces like glass as soon as any thing Comes that is Contrary to their traditions" (Ehat and Cook 1980, pp. 318-19, original spellings retained).

Smith's most protracted and ultimately successful attempt at democratizing his revelatory experiences came, however, through the creation of temple-based ritual. From quite early in his prophetic career, Smith was organizing what he called "endowment" experiences (with allusion to Luke 24:49): an experimental and arguably uneven experience in the summer of 1831, a more stable 
but unquestionably pentecostal experience in the spring of 1836, and then a more permanent ritual institution beginning in the spring of 1842 (for the historical context of each of these, see (Bushman 2005, pp. 155-60, 305-21, 436-58)). All three iterations of the endowment ritual were aimed, as Smith put it in 1842, at "setting forth ... all those plans \& principles by which any one is enabled to secure the fulness of those blessings which has been prepared for the chuch of the first-born, and come up, and abide in the presece of Eloheim in the eternal worlds". Further, these endowments were to be "made known to all saints, of the last days, so soon as they are prepared to recive, and a proper place is prepared to communicate them, even to the weakest of the saints" (Hedges et al. 2011, p. 54, original spellings retained). The endowment as it came into final form, so to speak, was less an ecstatic experience (as in the first two iterations) than a ritualized drama of preparing for and then entering into the presence of God. As Brigham Young famously defined the endowment drama in an 1853 sermon, it was meant from the beginning "to enable you to walk back to the presence of the Father, passing the angels who stand as sentinels" (Anderson 2011, p. 18). In the ritual enactment of the endowment, one witnessed or even experienced the creation of the world, the fall of humankind from paradise, and then a progression of sorts from "the telestial kingdom or the world" through "the terrestrial kingdom" to, at last, "the vail" and then "the Celestial Room", representing the presence of God (Anderson and Bergera 2005, p. 3). All of this took place in a consecrated temple.

This ultimate, ritualized version of divine endowment from 1842 thus traded directly on the 1832 vision account in which Smith and Rigdon presented their own apocalyptic experience. Previously, I noted aspects from early in their vision report, regarding their visions of Jesus Christ, of Satan, and of the devil's followers. But the vast majority of the vision report details three progressively heavenly kingdoms to which Smith gave the names "telestial", "terrestrial", and "celestial". The connection between the 1842 ritual drama and the 1832 vision report strongly suggests that Smith understood the ritualized endowment to be a means of extending his own apocalyptic vision—albeit in ritual form-to every worthy Latter-Day Saint. What he and Rigdon experienced ecstatically, every believer could experience in some kind of form. Through proper authority, one's undergoing such an experience, even in ritual form, might be regarded as having occurred in the deepest way possible. Through the endowment, every Latter-Day Saint experiences the apocalyptic in a direct fashion.

This is not the place for a history of the endowment ritual, nor for an extended argument about the (relatively obvious) relationship between the Smith-and-Rigdon vision of 1832 and the basic shape of the endowment ceremony. The incorporation of the vision's modifications to early Latter-Day Saint apocalyptic expectations into a ritualized format, democratically extending visions to all believers through a liturgical experience, is enough to clarify the contours of a hypothesis regarding the roots of the moderate millenarianism that is evident in twenty-first-century Latter-Day Saint practice and believe. The endowment ritual inaugurated in 1842 remains-despite occasional changes-central to Latter-Day Saint worship into the present (see Davies 2000, pp. 70-84). Latter-Day Saints in the mainstream branch of Smith's Restoration movement routinely engage themselves in a ritualized version of Smith's own apocalyptic visionary experience from 1832, which in turn seems to have been tied to apocalyptic anticipations directly within The Book of Mormon. The new millennium has seen some apparent decline in interest in the ritualized endowment experience among younger Latter-Day Saints (see Riess 2019, pp. 49-68), perhaps a predictable result as the Latter-Day Saint mainstream comes into more consistent interaction with the larger secular world and its displacement of the preferential option for religiosity (see, of course, Taylor 2007). By contrast with declining rates of church-going activity among other Christianities in the early twenty-first century, however, Latter-Day Saints remain strikingly religious (see Riess 2019, pp. 13-32). And nonetheless, the apocalyptic remains-in a strikingly moderate but ritualized form - at the center of contemporary Latter-Day Saint worship.

Funding: This research received no external funding.

Conflicts of Interest: The author declares no conflicts of interest. 


\section{References}

Anderson, Devery S., ed. 2011. The Development of LDS Temple Worship, 1846-2000: A Documentary History. Salt Lake City: Signature Books.

Anderson, Devery S., and Gary James Bergera, eds. 2005. The Nauvoo Endowment Companies, 1845-1846: A Documentary History. Salt Lake City: Signature Books.

Ashurst-McGee, Mark, David W. Grua, Elizabeth A. Kuehn, Brenden W. Rensink, and Alexander L. Baugh, eds. 2017. The Joseph Smith Papers, Documents: February 1838-August 1839. Salt Lake City: Church Historian's Press, vol. 6.

Ashurst-McGee, Mark, Brian M. Hauglid, and Michael Hubbard MacKay, eds. Forthcoming. Producing Ancient Scripture. Salt Lake City: University of Utah Press.

Baugh, Alexander L. 2005. Parting the Veil: Joseph Smith's Seventy-Six Documented Visionary Experiences. In Opening the Heavens: Accounts of Divine Manifestations, 1820-1844. Edited by John W. Welch. Salt Lake City: Deseret Book, Provo: Brigham Young University Press, pp. 264-326.

Bloom, Harold. 1992. The American Religion: The Emergence of the Post-Christian Nation. New York: Simon \& Schuster. Blythe, Christopher James. Forthcoming. Terrible Revolution: Latter-Day Saints and the American Apocalypse. New York: Oxford University Press.

Bracht, John. 1990. The Americanization of Adam. In Cargo Cults and Millenarian Movements: Transoceanic Comparisons of New Religious Movements. Edited by Garry W. Trompf. New York: Mouton De Gruter, pp. 97-142.

Bringhurst, Newell G., and John C. Hamer, eds. 2007. Scattering of the Saints: Schism within Mormonism. Independence: John Whitmer Books.

Burdon, Christopher. 1997. The Apocalypse in England: Revelation Unravelling, 1700-1834. New York: St. Martin's Press.

Bushman, Richard Lyman. 2005. Joseph Smith, Rough Stone Rolling: A Cultural Biography of Mormonism's Founder. New York: Alfred A. Knopf.

Chilton, Bruce. 2013. Visions of the Apocalypse: Receptions of John's Revelation in Western Imagination. Waco: Baylor University Press.

Cloward, Robert A. 1998. Isaiah 29 and the Book of Mormon. In Isaiah in the Book of Mormon. Edited by Donald W. Parry and John W. Welch. Provo: FARMS, pp. 191-247.

Davidson, Karen Lynn, David J. Whittaker, Mark Ashurst-McGee, and Richard L. Jensen, eds. 2012. The Joseph Smith Papers, Histories: Joseph Smith Histories, 1832-1844. Salt Lake City: Church Historian's Press, vol. 1.

Davies, Douglas J. 2000. The Mormon Culture of Salvation: Force, Grace, and Glory. Burlington: Ashgate.

Ehat, Andrew F., and Lyndon W. Cook, eds. 1980. The Words of Joseph Smith: The Contemporary Accounts of the Nauvoo Discourses of the Prophet Joseph. Provo: BYU Religious Studies Center.

Faulring, Scott H., Kent P. Jackson, and Robert J. Matthews, eds. 2004. Joseph Smith's New Translation of the Bible: Original Manuscripts. Provo: BYU Religious Studies Center.

Feldman, Noah R. 2015. Mormonism in the American Political Domain. In The Oxford Handbook of Mormonism. Edited by Terryl L. Givens and Philip L. Barlow. New York: Oxford University Press, pp. 606-21.

Firth, Katharine R. 1979. The Apocalyptic Tradition in Reformation Britain, 1530-1645. New York: Oxford University Press.

Frederick, Nicholas J. 2016. The Bible, Mormon Scripture, and the Rhetoric of Allusivity. Madison: Fairleigh Dickinson University Press.

Frederick, Nicholas J. 2018. The Book of Mormon and Its Redaction of the King James New Testament: A Further Evaluation of the Interaction between the New Testament and the Book of Mormon. Journal of Book of Mormon Studies 27: 44-87.

Gileadi, Avraham. 2005. Studies in the Book of Mormon. San Diego: Hebron Books.

Gileadi, Avraham. 2013. Apocalyptic Commentary on the Book of Isaiah. San Diego: Hebraeus Press.

Gilsdorf, Joy. 1989. The Puritan Apocalypse: New England Eschatology in the Seventeenth Century. New York: Garland Publishing.

Givens, Terryl L. 2002. By the Hand of Mormon: The American Scripture That Launched a New World Religion. New York: Oxford University Press.

Givens, Terryl L. 2009. The Book of Mormon: A Very Short Introduction. New York: Oxford University Press. 
Godfrey, Matthew C., Mark Ashurst-McGee, Grant Underwood, Robert J. Woodford, and William G. Hartley, eds. 2013. The Joseph Smith Papers, Documents: July 1831-January 1833. Salt Lake City: Church Historian's Press, vol. 2.

Hardy, Grant. 2010. Understanding the Book of Mormon: A Reader's Guide. New York: Oxford University Press.

Hardy, Grant. 2018. The Book of Mormon as Post-Canonical Scripture. In The Expanded Canon: Perspectives on Mormonism and Sacred Texts. Edited by Blair G. Van Dyke, Brian D. Birch and Boyd J. Petersen. Salt Lake City: Greg Kofford Books, pp. 73-84.

Hardy, Heather, and Grant Hardy. 2016. How Nephi Shapes His Readers' Perceptions of Isaiah. In Reading Nephi Reading Isaiah: 2 Nephi 26-27, 2nd ed. Edited by Joseph M. Spencer and Jenny Webb. Provo: Neal A. Maxwell Institute, pp. 33-58.

Harper, Steven C. 2005. "A Pentecost and Endowment Indeed": Six Eyewitness Accounts of the Kirtland Temple Experience. In Opening the Heavens: Accounts of Divine Manifestations, 1820-1844. Edited by John W. Welch. Salt Lake City: Deseret Book, Provo: Brigham Young University Press, pp. 327-71.

Harrison, John Fletcher Clews. 1979. The Second Coming: Popular Millenarianism, 1780-1850. London: Routledge \& Kegan Paul.

Hedges, Andrew H., Alex D. Smith, and Richard Lloyd Anderson, eds. 2011. The Joseph Smith Papers, Journals: December 1841-April 1843. Salt Lake City: Church Historian's Press, vol. 2.

Holifield, E. Brooks. 2003. Theology in America: Christian Thought from the Age of the Puritans to the Civil War. New Haven: Yale University Press.

Holland, David F. 2011. Sacred Borders: Continuing Revelation and Canonical Restraint in Early America. New York: Oxford Universiyy Press.

Hopkin, Shon D. 2016. Seeing Eye to Eye: Nephi's and John's Intertwining Visions of the Tree of Life. In Apocalypse: Reading Revelation 21-22. Edited by Julie M. Smith. Provo: Neal A. Maxwell Institute, pp. 66-84.

Jensen, Robin Scott, Robert J. Woodford, and Steven C. Harper, eds. 2009. The Joseph Smith Papers, Revelations and Translations (Facsimile Edition): Manuscript Revelation Books. Salt Lake City: Church Historian's Press, vol. 1.

Jensen, Robin Scott, Richard E. Turley Jr., and Riley M. Lorimer, eds. 2011. The Joseph Smith Papers, Revelations and Translations: Published Revelations. Salt Lake City: Church Historian's Press, vol. 2.

Johnston, Warren. 2011. Revelation Restored: The Apocalypse in Later Seventeenth-Century England. Rochester: Boydell Press.

Kirsch, Jonathan. 2006. A History of the End of the World: How the Most Controversial Book in the Bible Changed the Course of Western Civilization. San Francisco: HarperCollins.

Kovacs, Judith, and Christopher Rowland. 2004. Revelation: The Apocalypse of Christ. Malden: Blackwell.

Maffly-Kipp, Laurie F., ed. 2010. American Scriptures: An Anthology of Sacred Writings. New York: Penguin.

Miller, Perry. 1956. Errand into the Wilderness. Cambridge: Harvard University Press.

Moore, R. Laurence. 1986. Religious Outsiders and the Making of Americans. New York: Oxford University Press.

Moorhead, James H. 2000. Apocalypticism in Mainstream Protestantism, 1800 to the Present. In The Encyclopedia of Apocalypticism: Apocalypticism in the Modern Period and the Contemporary Age. Edited by Stephen J. Stein. New York: Continuum, vol. 3, pp. 72-107.

Morris, Larry E. 2019. A Documentary History of the Book of Mormon. New York: Oxford University Press.

Nemelka, Christopher. 2005. The Sealed Portion: The Final Testament of Jesus Christ. Lemon Grove: Worldwide United Publishing.

Numbers, Ronald L., and Jonathan M. Butler, eds. 1987. The Disappointed: Millerism and Millenarianism in the Nineteenth Century. Bloomington and Indianapolis: Indiana University Press.

Riess, Jana. 2019. The Next Mormons: How Millennials Are Changing the LDS Church. New York: Oxford University Press.

Robinson, Stephen E. 1998. Nephi's “Great and Abominable Church”. Journal of Book of Mormon Studies 7: 32-39, 70.

Romig, Ronald E., and John H. Siebert. 1990. First Impressions: The Independence, Missouri, Printing Operation, 1832-33. John Whitmer Historical Association Journal 10: 51-66.

Shipps, Jan. 1985. Mormonism: The Story of a New Religious Tradition. Urbana and Chicago: University of Illinois Press. Skousen, Royal, ed. 2009. The Book of Mormon: The Earliest Text. New Haven: Yale University Press.

Spencer, Joseph M. 2011. The Four Discourses of Mormonism. BYU Studies 50: 1-21.

Spencer, Joseph M. 2014. Christ and Krishna: The Visions of Arjuna and the Brother of Jared. Journal of Book of Mormon Studies 23: 56-80. 
Spencer, Joseph M. 2016a. The Vision of All: Twenty-five Lectures on Isaiah in Nephi's Record. Salt Lake City: Greg Kofford Books.

Spencer, Joseph M. 2016b. The Book, the Words of the Book: What the Book of Mormon Says about Its Own Coming Forth. Religious Educator: Perspectives on the Restored Gospel 17: 64-81.

Stein, Stephen J. 2000. Apocalypticism outside the Mainstream in the United States. In The Encyclopedia of Apocalypticism: Apocalypticism in the Modern Period and the Contemporary Age. Edited by Stephen J. Stein. New York: Continuum, vol. 3, pp. 108-39.

Taubes, Jacob. 2009. Occidental Eschatology. Translated by David Ratmoko. Stanford: Stanford University Press. Taylor, Charles. 2007. A Secular Age. Cambridge: Harvard University Press.

Turley, Kylie. Forthcoming. Alma's Hell: Repentance, Consequence, and the Lake of Fire and Brimstone. Journal of Book of Mormon Studies 28.

Underwood, Grant. 1993. The Millenarian World of Early Mormonism. Urbana and Chicago: University of Illinois Press.

Van Dyke, Blair G., Brian D. Birch, and Boyd J. Petersen, eds. 2018. The Expanded Canon: Perspectives on Mormonism and Sacred Texts. Salt Lake City: Greg Kofford Books.

Woodford, Robert J. 2010. Joseph Smith and "The Vision", 1832. In Joseph Smith, the Prophet and Seer. Edited by Richard Neitzel Holzapfel and Kent P. Jackson. Salt Lake City: Deseret Book, Provo: BYU Religious Studies Center, pp. 101-126.

Zakai, Avihu. 1992. Exile and Kingdom: History and Apocalypse in the Puritan Migration to America. New York: Cambridge University Press.

(C) 2019 by the author. Licensee MDPI, Basel, Switzerland. This article is an open access article distributed under the terms and conditions of the Creative Commons Attribution (CC BY) license (http://creativecommons.org/licenses/by/4.0/). 